\title{
SISTEM PEMESANAN MAKANAN DAN MINUMAN DI OSAKA RAMEN DEPOK BERBASIS JAVA
}

\author{
ROBBY AWALDI \\ HARRY DHIKA \\ Program Studi Informatika, Universitas Indraprasta PGRI \\ Email: robbyawaldi@gmail.com \\ dhikatr@yahoo.com
}

\begin{abstract}
Abstrak. Osaka Ramen Depok adalah restoran yang menyediakan masakan khas Jepang khususnya ramen. Osaka Ramen Depok dalam proses bisnisnya masih menggunakan sistem manual dalam pemesanannya yaitu pemesanan konvensional yang masih menggunakan kertas dan pulpen untuk mencatat pesanan. Jumlah pengunjung yang semakin meningkat membutuhkan bantuan proses komputerisasi sehingga kebutuhan staf terus meningkat, hal ini harus dibantu dengan migrasi sistem komputerisasi. Tujuan penelitian ini adalah untuk membuat sistem pemesanan menjadi sistem yang terkomputerisasi sehingga dapat mempercepat proses pemesanan, menghindari kesalahan pesanan, dan pengolahan data laporan pemesanan menjadi lebih mudah. Metode penelitian yang digunakan adalah metode deskriptif, yaitu metode untuk berusaha mengumpulkan, menyajikan, serta menganalisis data sehingga dapat memberikan gambaran yang jelas. Metode Diagram Alir Data (DAD) digunakan untuk memberikan ilustrasi proses kegiatan. Metode pengumpulan dilakukan dengan studi lapangan yang meliputi observasi, studi literatur, dan wawancara. Langkah-langkah pengembangan sistem menggunakan model SDLC (System Development Life Cycle). Hasil yang dapat disimpulkan adalah dengan mengimplementasikan sistem pemesanan yang terkomputerisasi dapat membuat proses pemesanan menjadi lebih efektif dan efisien. Hasil Penelitian ini juga diterapkan pada rumah makan Osaka Ramen Depok.
\end{abstract}

Kata Kunci : Sistem, Pemesanan, Java, Makanan

Abstract. Osaka Ramen Depok is a restaurant that offers Japanese specialties, especially ramen. Osaka Ramen Depok in its business process is still using the manual system in ordering namely conventional orders that still use paper and pens to record orders. The increasing number of visitors requires the help of a computerized process so that the need for staff continues to increase, this must be helped by the migration of computerized systems. The purpose of this study is to make the ordering system a computerized system so that it can speed up the ordering process, avoid order errors, and order data processing reports more easily. The research method used is descriptive method, which is a method for trying to collect, present, and analyze data so that it can provide a clear picture. The Data Flow Diagram (DAD) method is used to illustrate the activity process. The collection method is carried out by field studies which include observations, literature studies, and interviews. The steps of developing the system use the SDLC (System Development Life Cycle) model. The result that can be concluded is by implementing a computerized ordering system that can make the ordering process more effective and efficient. The results of this study were also applied to the Osaka Ramen Depok restaurant.

Key Words : System, ordering, Java, Food

\section{PENDAHULUAN}

Saat ini perkembangan teknologi informasi berkembang dengan pesat dan banyak dimanfaatkan untuk memenuhi aktivitas atau pekerjaan manusia. Banyak pekerjaan manusia yang sebelumnya menggunakan sistem manual dapat diubah menjadi sistem yang terkomputerisasi. Meskipun teknologi informasi sudah berkembang pesat, tetapi masih saja terdapat sistem manual yang masih dipertahankan. Salah satu sistem manual yang masih dipertahankan sampai saat ini adalah sistem pemesanan makanan menggunakan cara konvensional. 
Sistem pemesanan bersifat konvensional mengandalkan pelayan untuk melayani pemesanan setiap pelanggan dengan mencatat pesanan menggunakan alat tulis dan kertas. Sistem pemesanan yang bersifat konvensional ini sering kali terdapat permasalahan yang ditimbulkan, salah satunya adalah saat tempat makan tersebut sedang ramai, pelayan akan sangat sibuk melayani pelanggan, dan pelanggan yang baru datang harus menunggu pelayan agar dapat melakukan pemesanan. Masalah ini terjadi di Osaka Ramen Depok yang masih menggunakan sistem pemesanan bersifat konvensional.

Osaka Ramen Depok adalah resto yang menjual bermacam-macam jenis ramen khas Jepang dan juga terdapat berbagai masakan Indonesia. Seperti yang dijelaskan di atas, Osaka Ramen Depok masih menggunakan sistem pemesanan yang bersifat konvensional. Oleh karena itu, perlu dibuat sistem pemesanan makanan dan minuman di osaka ramen depok berbasis java. Sistem pemesanan yang dibuat diharapkan dapat membantu mempercepat proses pemesanan di Osaka Ramen Depok.

Sistem adalah kumpulan dari elemen yang saling berhubungan dan bekerja sama untuk mencapai suatu tujuan (Sujarweni, 2015). Selain itu, pengertian dari sistem sebagai kumpulan atau himpunan dari unsur, komponen, atau variabel yang terorganisir, saling berinteraksi satu sama lain, dan terpadu (Sutabri, 2012).

Pemesanan adalah suatu aktivitas yang dilakukan oleh konsumen sebelum membeli (Rahman, 2015). Pemesanan memiliki arti yang luas tergantung objek apa yang dituju. Dalam penelitian ini pengertian pemesanan adalah suatu proses yang dilakukan pelanggan restoran untuk memesan makanan dan minuman yang tersedia di daftar menu.

Bahasa pemrograman Java merupakan salah satu dari sekian banyak bahasa pemrograman yang dapat dijalankan di berbagai sistem operasi termasuk telepon genggam (Nofriadi, 2015). Java merupakan bahasa pemrograman berorientasi objek yang dikembangkan oleh Sun Microsystem yang dimulai oleh James Gosling dan dirilis pada tahun 1995, saat ini Sun Microsystem telah di akuisisi oleh Oracle Corporation (Enterprise, 2015).

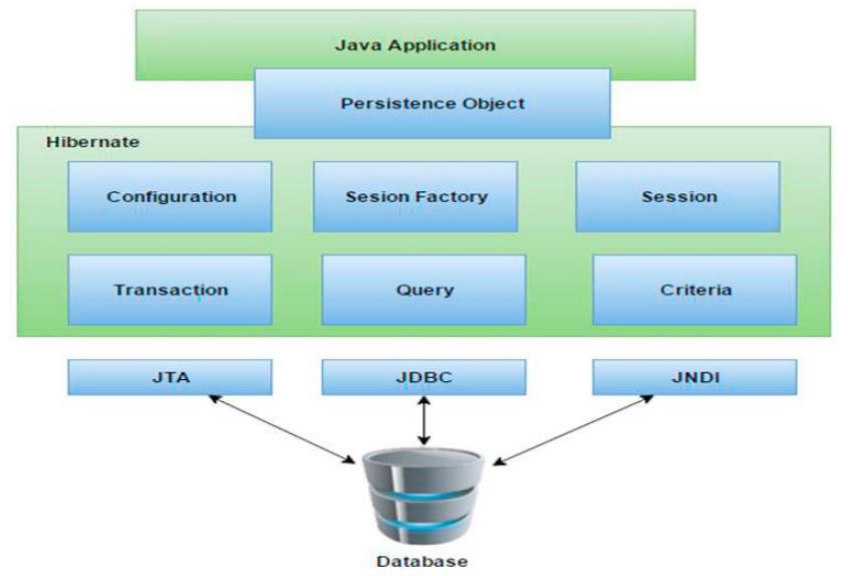

Gambar 1. Java Framework(Ginanjar \& Hendayun, 2019)

Bahasa Java memberi harapan menjadi perekat universal yang menghubungkan pemakai dengan informasi dari web server, basis data, penyedia informasi dan sumber-sumber lain (Hariyanto, 2014). Java dapat digunakan di berbagai platform dikarenakan program Java berjalan menggunakan Java virtual machine (JVM). JVM inilah yang membuat program Java hanya perlu ditulis sekali dan dapat digunakan di berbagai sistem operasi dan platform. Java termasuk bahasa pemrograman berorientasi objek dikarenakan dalam bahasa Java semua sintaksis atau kode harus berada di dalam suatu class yang nantinya akan diimplementasikan menjadi sebuah objek

\section{METODE}

Penulis melakukan penelitian dari bulan Februari sampai Juni 2019. Metode penelitian yang digunakan adalah metode deskriptif. Metode deskriptif adalah metode untuk berusaha mengumpulkan, 
menyajikan, serta menganalisis data sehingga dapat memberikan gambaran yang jelas. Dalam penelitian ini terdapat beberapa jenis data dan sumber data yang digunakan. Metode pengumpulan data yang digunakan penulis adalah studi lapangan yang meliputi observasi, studi literatur, dan wawancara. Tujuan observasi yaitu untuk mengetahui secara langsung sistem atau metode pemesanan yang digunakan di Osaka Ramen Depok. Untuk dapat menyelesaikan permasalahan penulis melakukan studi literatur berdasarkan buku-buku dan jurnal yang berhubungan dengan permasalahan dalam penelitian ini. Pada penelitian ini dilakukan wawancara di mana narasumber adalah pemilik atau owner dari Osaka Ramen Depok dan pewawancara adalah penulis sendiri. Langkah-langkah pengembangan sistem menggunakan model SDLC (System Development Life Cycle)(Broad, 2013). Pembahasan SDLC dengan lengkap bersumber dari (McDowall, 1991) dengan dikembangkan hingga kini seperti pada gambar 1 .

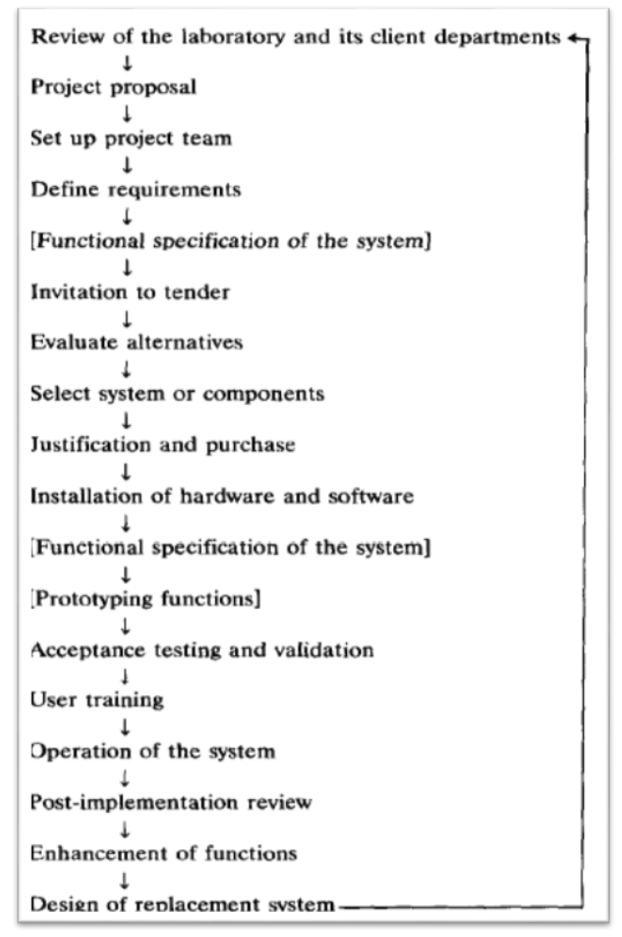

Gambar 1. Tahapan Awal SDLC (McDowall, 1991)

Terdapat 17 tahapan awal yang dilakukan dalam system development life cycle oleh McDowall, sehingga kini pengembangan system harus disederhanakan dan dirampingkan namun tidak mengurangi inti dari kualitas pengembangan. Konsep dasarnya sama dengan memulai dari rencana proposal hingga tahapan desain replacement system setelah melalui tahapan implementasi system. 


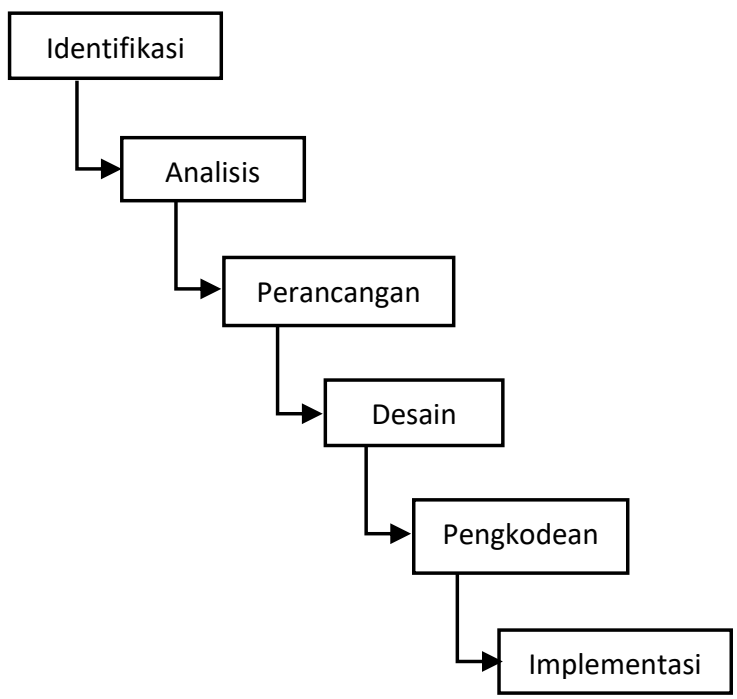

Gambar 2. Metode pengembangan $S D L C$

\section{HASIL DAN PEMBAHASAN}

Hasil dari penelitian ini dapat dilihat dari manfaat yang dihasilkan oleh sistem pemesanan yang dibuat. Sistem pemesanan yang saat ini digunakan menggunakan sistem pemesanan konvensional yang masih memiliki risiko kesalahan data pesanan, sehingga perlu dibuat sistem pemesanan yang terkomputerisasi yang dapat menekan risiko kesalahan serta lebih efektif dan efisien saat pemesanan.

Aturan bisnis yang diusulkan dibuat untuk menyesuaikan dengan sistem yang baru, yaitu pelanggan memesan menggunakan komputer yang disediakan di setiap meja yang sudah terdapat aplikasi untuk memesan. Setelah memesan melalui aplikasi client, pelanggan hanya tinggal menunggu pesanan diantarkan ke meja tersebut. Jika pelanggan merasa kurang dengan pesanannya, pelanggan dapat memesan kembali menggunakan aplikasi yang sama. Tetapi jika pelanggan telah menekan tombol bayar di dalam aplikasi tersebut, pelanggan harus menyelesaikan pembayaran terlebih dahulu jika ingin kembali memesan. Untuk melakukan pembayaran pelanggan dapat menekan tombol bayar di aplikasi client dan menunggu pelayan untuk mengantarkan bill atau tagihan pembayaran. Setelah itu pelanggan dapat membayar tagihan kepada pelayan. Pelayan akan kembali ke komputer server untuk menyelesaikan pembayaran dan mencetak bukti pembayaran.

Dekomposisi fungsi merupakan pemecahan fungsi-fungsi yang lebih kecil sehingga sistem mudah untuk dipahami.

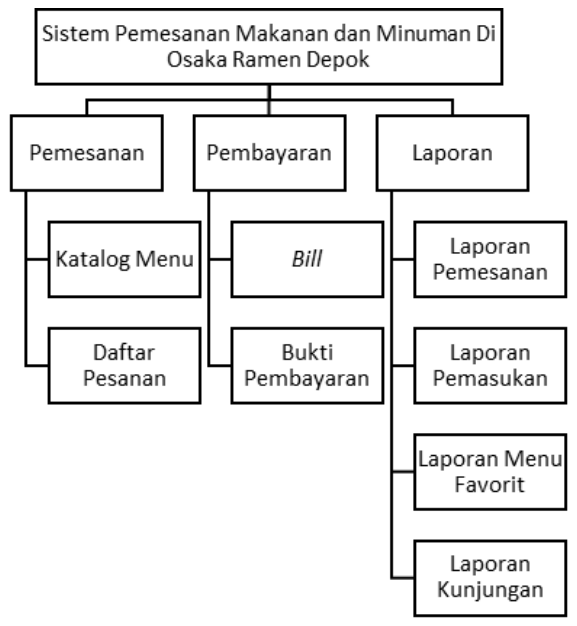

Gambar 3. Dekomposisi Fungsi 
Perancangan Data Flow Diagram terdiri dari notasi proses, entitas, simpanan data, dan alur data. DFD menggambarkan suatu sistem menjadi sub sistem yang lebih kecil dan arus data yang dikirim antar sub sistem.

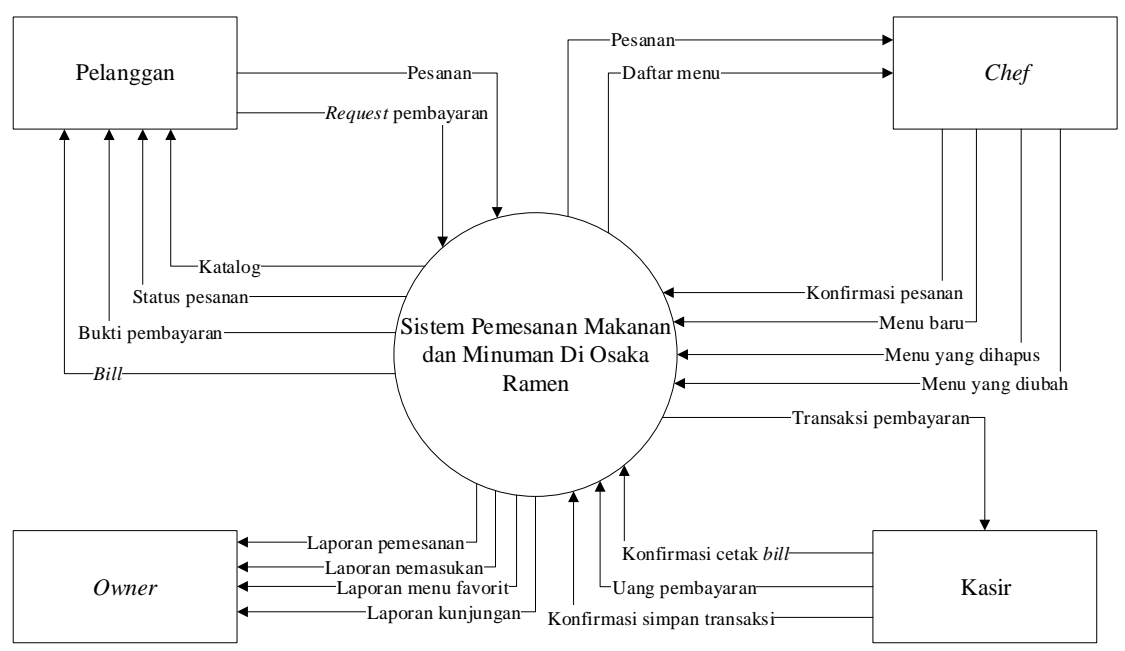

\section{Gambar 4. Diagram Konteks}

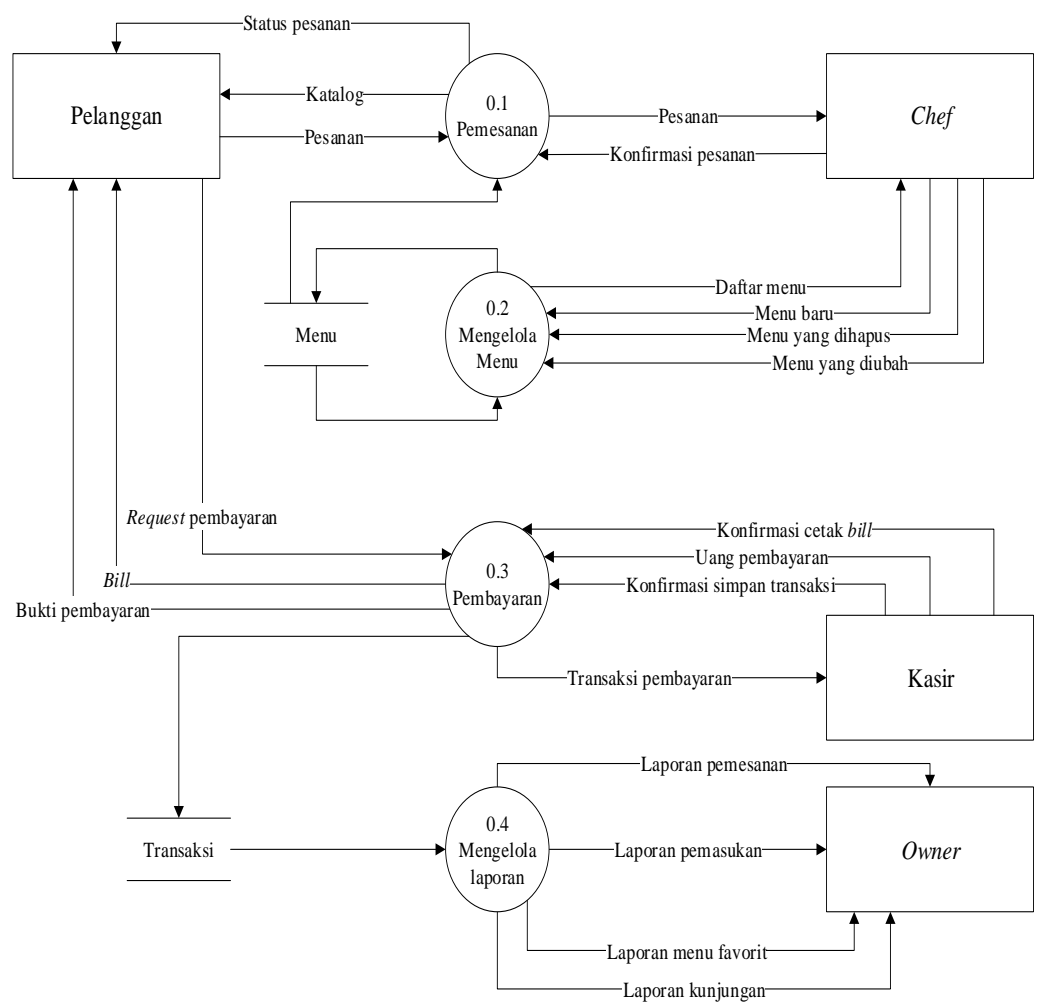

Gambar 5. Diagram Nol

Perancangan database secara konseptual terdiri atas tiga langkah yaitu membuat entitas berdasarkan data yang ada di lapangan, mencari hubungan yang ada antar entitas, membuat atau menggambarkan entitas dan hubungan antar entitas ke dalam bentuk diagram. 
Faktor Exacta 12 (4): 262-271, 2019

p-ISSN: 1979-276X

e- ISSN: 2502-339X

DOI: $10.30998 /$ faktorexacta.v12i4.4623

Awaldi, Dhika-Sistem Pemesanan Makanan dan.....

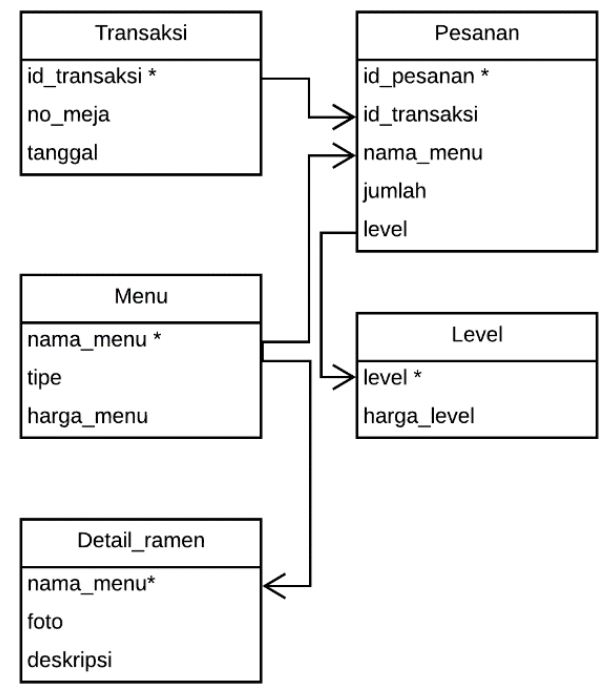

Gambar 6. Normalisasi Tabel

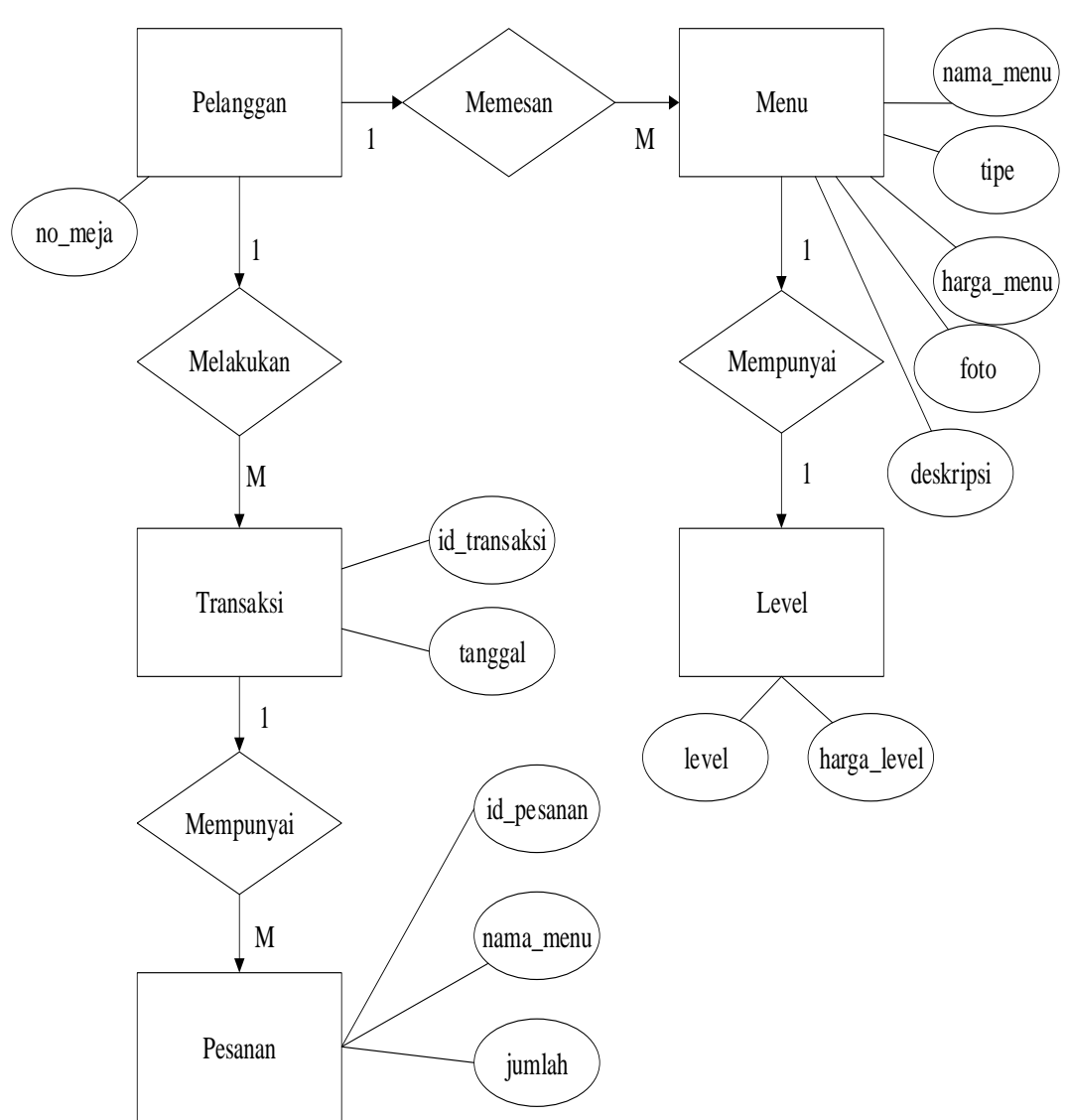

Gambar 7. Diagram ERD

Tampilan layar antar muka pada sistem pemesanan Osaka Ramen Depok adalah sebagai berikut: 
Faktor Exacta 12 (4): 262-271, 2019

p-ISSN: 1979-276X

e- ISSN: 2502-339X

DOI: $10.30998 /$ faktorexacta.v12i4.4623

Awaldi, Dhika-Sistem Pemesanan Makanan dan.....

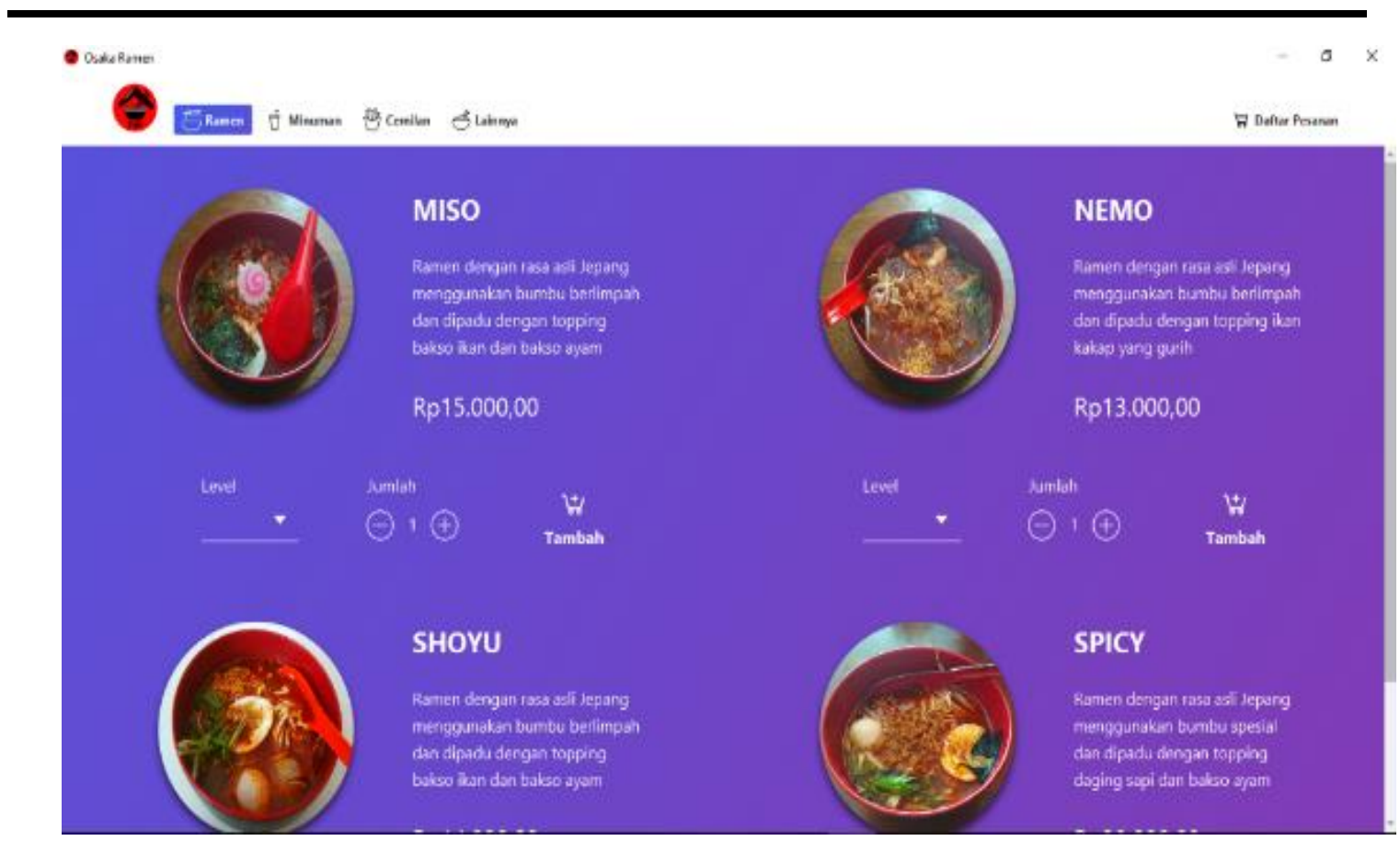

Gambar 8. Daftar Menu

Pada tampilan daftar menu. Pelanggan dapat melakukan pesanan, memilih level kepedasan, menentukan jumlah pesanan yang ada di setiap bawah menu. Setelah menentukan level dan jumlah, pelanggan dapat menekan tombol tambah. Pesanan akan disimpan ke dalam daftar pesanan.

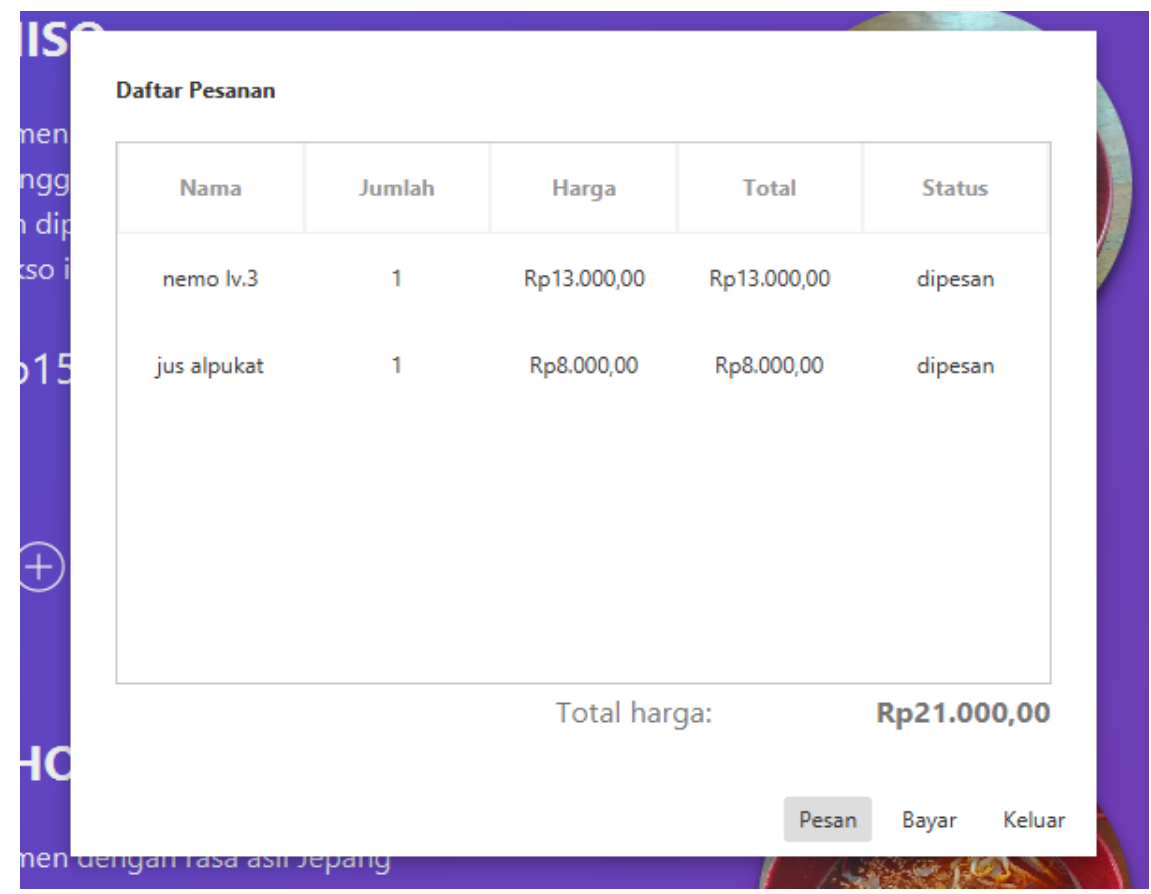

Gambar 9. Daftar Pesanan

Daftar pesanan berfungsi untuk menampilkan daftar pesanan yang sudah ditambahkan. Untuk melakukan pemesanan, pelanggan dapat menekan tombol pesan, kemudian akan muncul dialog konfirmasi untuk memastikan bahwa data pesanan sudah benar. Apabila konfirmasi diterima, pesanan akan dikirim ke komputer server dan status pesanan akan berubah menjadi dipesan. Untuk melakukan 
pembayaran dapat menekan tombol bayar. Pembayaran dapat dilakukan setelah semua pesanan diproses di dapur. Untuk keluar dari daftar pesanan, pelanggan dapat menekan tombol keluar.

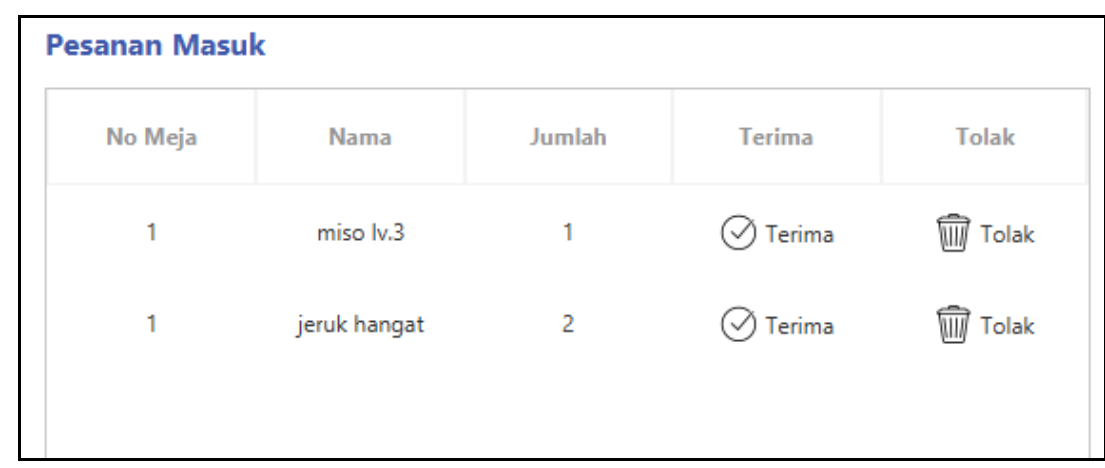

Gambar 10. Pesanan Masuk

Pada tampilan pesanan masuk. Jika terdapat pesanan masuk maka akan muncul pada tabel pesanan masuk yang berisi data pesanan seperti nomor meja, nama pesanan, jumlah pesanan. Kemudian data tersebut dapat dikonfirmasi apakah pesanan dapat diterima karena stok di dapur tersedia atau dapat ditolak karena tidak ada stok atau alasan lain.

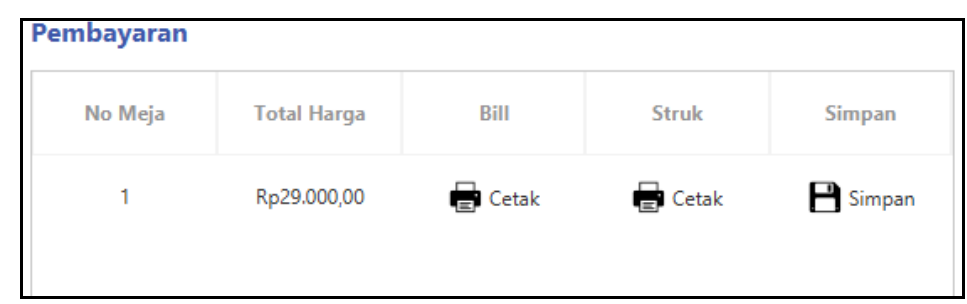

Gambar 11. Pembayaran

Pada tampilan pembayaran. data pembayaran atau transaksi akan muncul apabila ada pelanggan yang melakukan permintaan untuk melakukan pembayaran. Data pada tabel pembayaran berupa nomor meja, total pembayaran. Pelayan atau kasir dapat melakukan pencetakan bill untuk diantarkan ke meja pelanggan. Setelah pelanggan membayar, pelayan atau kasir dapat memasukkan nominal uang pembayaran dengan menekan terlebih dahulu tombol cetak struk. Setelah transaksi selesai, transaksi dapat disimpan ke database dengan menekan tombol simpan. 
Faktor Exacta 12 (4): 262-271, 2019

p-ISSN: 1979-276X

e- ISSN: 2502-339X

DOI: $10.30998 /$ faktorexacta.v12i4.4623

Awaldi, Dhika-Sistem Pemesanan Makanan dan.....

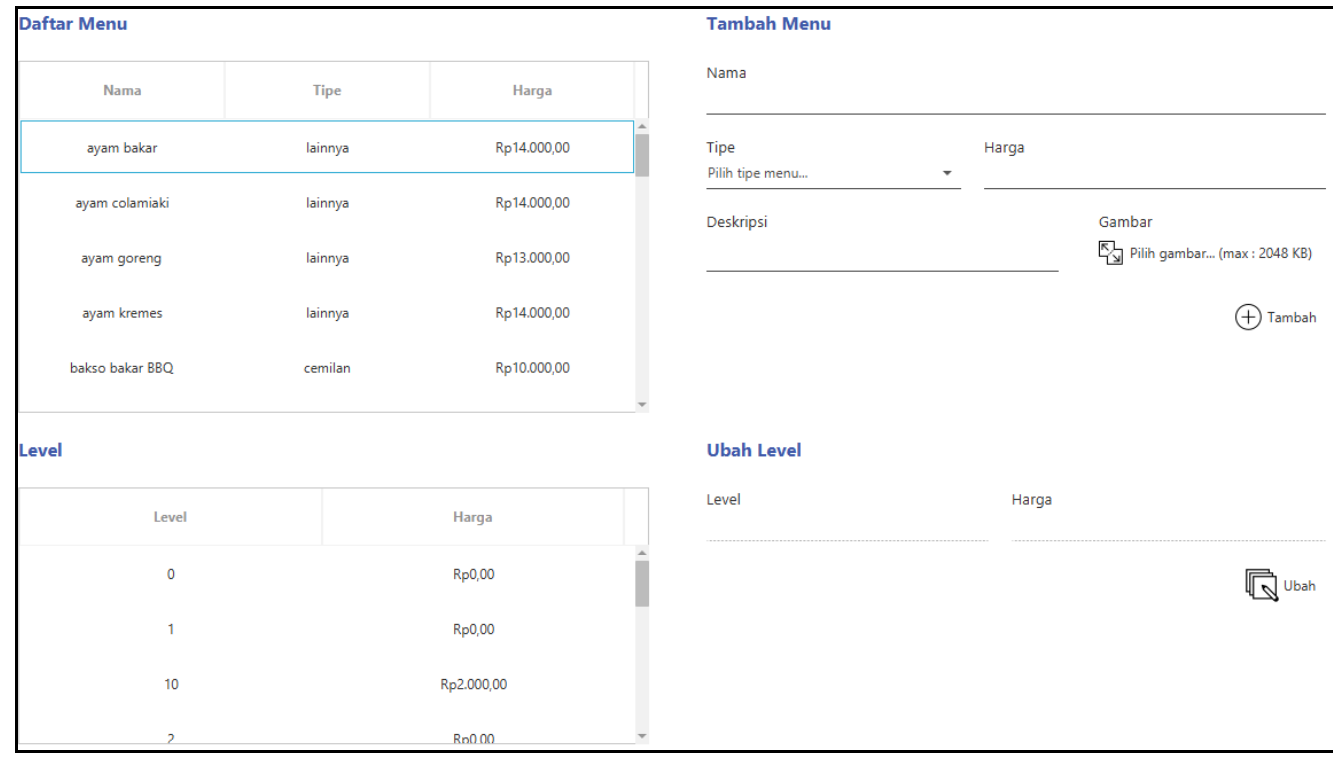

\section{Gambar 12. Daftar Menu Admin}

Pada tampilan daftar menu admin digunakan untuk mengelola daftar menu. Tampilan ini hanya dapat diakses oleh pemilik Osaka Ramen. Tampilan ini digunakan untuk mengelola data menu seperti menambah data menu, mengubah data menu, dan menghapus data menu. Selain mengelola daftar menu, juga terdapat fitur untuk mengelola harga level.

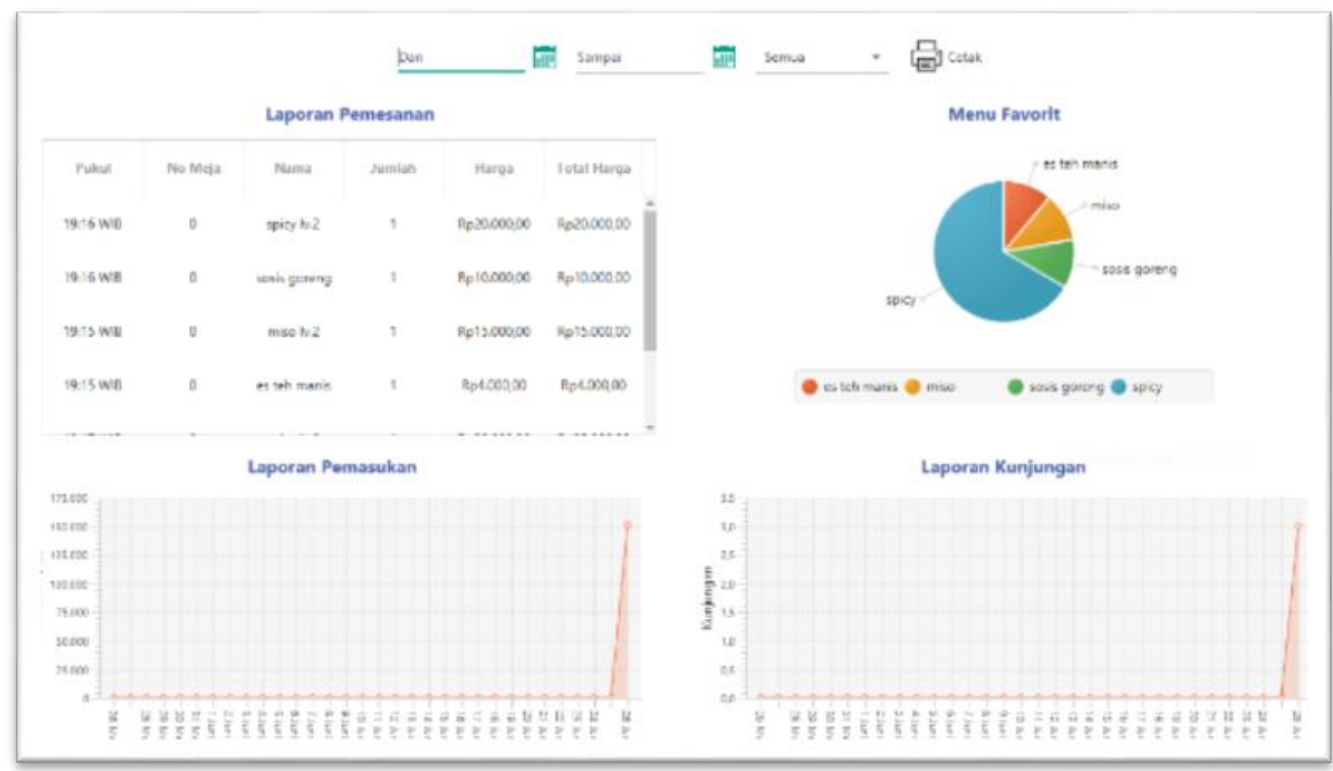

Gambar 13. Tampilan Laporan

Pada tampilan laporan-laporan yaitu laporan pemesanan, laporan menu favorit, laporan pemasukan, dan laporan kunjungan. Tampilan ini hanya dapat diakses oleh pemilik Osaka Ramen. Setiap laporan terdapat tombol untuk menampilkan laporan yang lebih rinci dalam bentuk pdf. Tampilan laporan merupakan hasil pengembangan akhir program ini dipakai oleh Osaka Ramen Depok. 


\section{PENUTUP}

Simpulan

Dari pembahasan di atas dapat disimpulkan bahwa proses pencatatan secara komputerisasi dapat memberikan suatu daya tarik yang berbeda kepada pelanggan, mengurangi risiko kesalahan data pesanan, serta mengurangi pekerjaan pelayan karena proses pencatatan pesanan sudah ditangani oleh komputer. Data-data pesanan yang terkumpul langsung diolah dalam bentuk laporan sehingga pelayan Osaka Ramen tidak perlu menghitung semua rangkap bukti pembayaran secara manual. Terdapat laporan menu favorit yang bermanfaat sebagai bahan untuk pengambil keputusan dalam menjalankan bisnis restoran.

\section{DAFTAR PUSTAKA}

Broad, J. (2013). System Development Life Cycle (SDLC). Risk Management Framework, 39-45. https://doi.org/10.1016/b978-1-59749-995-8.00005-3

Enterprise, J. (2015). Pengenalan Pemrograman Komputer. Jakarta: PT Elex Media Komputindo.

Ginanjar, A., \& Hendayun, M. (2019). ScienceDirect ScienceDirect ScienceDirect Spring Framework Reliability Investigation Against Database Spring Framework Reliability Investigation Against Database Bridging Layer Using Java Platform Bridging Layer Using Java Platform. Procedia Computer Science, 161, 1036-1045. https://doi.org/10.1016/j.procs.2019.11.214

Hariyanto, B. (2014). Esensi-Esensi Bahasa Pemrograman Java: Disertai Lebih Dari 100 Contoh Program. Bandung: Informatika.

McDowall, R. D. (1991). The Systems Development Team. Lanoratory Information Management, Elsevier, 13(13), 121-133.

Nofriadi. (2015). Java Fundamental Dengan Netbeans 8.0.2. Yogyakarta: DeePublish.

Rahman, F. (2015). Aplikasi pemesanan undangan online. Jurnal Sains Dan Informatika, 1(2), 78-87. Sujarweni, V. W. (2015). Sistem Akuntansi. Yogyakarta: Pustaka Baru Press.

Sutabri, T. (2012). Analisis Sistem Informasi. In Analisa Sistem Informasi. Jakarta: Andi. 